\title{
Tolbutamide-Induced Changes of the DNA, Protein and Insulin Content and the Secretory Activity of Isolated Rat Pancreatic Islets
}

\author{
P. Schauder and H. Frerichs \\ Dept. of Medicine, Division of Gastroenterology and Metabolism, University of Göttingen, Federal Republic of Germany
}

Received: March 12, 1975, and in revised form: May 16, 1975

\begin{abstract}
Summary. Following prolonged administration of tolbutamide the DNA- and protein content per islet was enhanced but the IRI content per islet was diminished. Glucose-induced $(2.0,8.0$ or 16.6 $\mathrm{mM})$ and leucine-induced $(12.5$ or $25.0 \mathrm{mM})$ IRI release from isolated islets, as well as ${ }^{14} \mathrm{CO}_{2}$-production from $\mathrm{U}-{ }^{14} \mathrm{C}$ glucose, were decreased. Theophylline $(5.0 \mathrm{mM})$ restored the glucose sensitivity of the islets towards normal. The results indicate that
\end{abstract}

tolbutamide-induced islet cell hyperplasia does not entail islet hyperfunction, as previously thought. Decreased IRI release may partially be explained by a tolbutamide-induced alteration of the adenylate cyclase/phosphodiesterase system of the B-cell.

Key words: Islet hyperplasia, islet DNA, islet protein, insulin release, tolbutamide treatment, theophylline.
Sulfonylurea compounds are thought to decrease blood glucose via increased insulin (IRI) release, but their detailed mode of action is still a matter of debate, particularly as far as the long-term effects of sulfonylureas are concerned (for review see ref. 1). Most studies have failed to show a correlation between decrease in blood glucose and increase in IRI levels after prolonged administration of sulfonylureas to patients [2-7]. Moreover, histomorphological observations on islet tissue after chronic administration of sulfonylureas have shown increased islet growth, which has usually been interpreted as indicative of islet hyperfunction [8-14], while biochemical studies indicate a diminished glucose tolerance and a decrease in IRI release and/or IRI content of the islets suggesting islet hypofunction [15-19].

We reinvestigated the influence on rat pancreatic islets of prolonged administration of tolbutamide, in a dosage known to induce maximal degranulation of the B-cells within 3 to 5 days, by studying concomitantly islet composition (content of DNA, protein and IRI), metabolic activity $\left(\mathrm{CO}_{2}\right.$-production) and secretory behaviour (IRI release induced by glucose, leucine and theophylline).

Decreased IRI release was found to occur in the presence of islet hyperplasia, thereby indicating that tolbutamide-induced increase in islet size does not entail islet hyperfunction, as previously thought. One of the possible reasons for the decreased secretory activity may be an alteration in the adenylate cyclase/ phosphodiesterase system of the B-cell.

\section{Materials and Methods}

Ficoll (lot 4556) was obtained from Pharmacia Fine Chemicals AB, Uppsala, Sweden; 3,5-diaminobenzoic acid dihydrochloride (lot A2A) from Eastman Kodak Co., Rochester, New York, USA; salmon sperm DNA (lot 15776) from Boehringer Mannheim $\mathrm{GmbH}$, Mannheim, FRG; Hyamine-hydroxide from Koch-Light Lab. Ltd, Colnbrock, England; Dimilume from Packard Instrument Co., Warrenville, Illinois, USA; Altromin from Spezialfutterwerke, Lage, FRG; U- ${ }^{14} \mathrm{C}$ glucose $(0.25 \mathrm{mC} / 13.4 \mathrm{mg}$, lot $299-022)$ from New England Nuclear Inc., Boston, Massachusetts, USA. Further reagents used are listed in a previous report [20].

Male Wistar rats fed Altromin and water ad libitum received Na-tolbutamide $\left(\right.$ Rastinon $\left.{ }^{R}\right) 500 \mathrm{mg} / \mathrm{kg}$ twice daily for 7-9 days or for 29-54 days by an oesophageal tube. The mean initial body weight of long-term treated animals both in the tolbutamide group $(\mathrm{n}=28)$ and the controls $(\mathrm{n}=28)$ was $223 \mathrm{~g}$, while the final body weight was 275 vs $278 \mathrm{~g}$, respectively. The mean initial body weight of short-term treated animals, both in the tolbutamide group $(\mathrm{n}=10)$ and the controls $(\mathrm{n}=10)$, was $218 \mathrm{~g}$, while the final body weight was 238 vs $232 \mathrm{~g}$ respectively.

Islets, isolated from rat pancreas by collagenase digestion [21] and purified by a discontinuous Ficoll gradient [22], were incubated as previously described [20] with concentrations of glucose, leucine and the- 
ophylline indicated in the tables. The average number of islets collected per pancreas of tolbutamide-treated and control rats was nearly identical ( $305 \mathrm{vs.} 290$ ). IRI from the medium was determined by radioimmunoassay with rat insulin as a standard [23]. Production of ${ }^{14} \mathrm{CO}_{2}$ from $\mathrm{U}^{14} \mathrm{C}$ glucose (specific activity in the medium $0.12 \mathrm{mC} / \mathrm{mmol}$ glucose) was measured by incubating groups of 25 islets for $3 \mathrm{~h}$ in flasks holding a glass well and closed with a rubber stopper. Experiments were preceded by a 5 min equilibration period with an $\mathrm{O}_{2}-\mathrm{CO}_{2}$ mixture $(95 \%: 5 \%)$ and terminated by injecting $0.2 \mathrm{ml}$ of $10 \mathrm{~N} \mathrm{H}_{2} \mathrm{SO}_{4}$ into the medium and $0.5 \mathrm{ml}$ of Hyamine-hydroxide into the glass well. After a collection period of $90 \mathrm{~min} \mathrm{Hy}-$ amine was transferred to scintillation vials containing $10.0 \mathrm{ml}$ Dimilume. Radioactivity was measured in a Beckman Tricarb liquid scintillation Spectrometer (model 3380) equipped with a computer unit (model 544) for quench correction by external standardisation. Extraction and measurement of total IRI, alkali soluble protein and DNA from islets was as described by Green and Taylor [24].

\section{Results}

The protein content of islets of rats treated for 7-9 days with tolbutamide was almost identical to that of control islets, whereas the extractable IRI content was significantly lower. By contrast, islets from rats treated for at least 29 days with tolbutamide and sacrificed 24 or $2 \mathrm{~h}$ after the last dose had a higher protein and DNA content than the appropriate controls, while their IRI content was lower. The protein/DNA ratio was found to be nearly identical in each of the four groups (Table 1).

Islets from these long-term treated rats produced ${ }^{14} \mathrm{CO}_{2}$ from $\mathrm{U}^{14} \mathrm{C}$-glucose at a lower rate than control islets, both at low $(5.0 \mathrm{mM})$ and high $(16.6 \mathrm{mM})$ glucose concentration. In the presence of $5.0 \mathrm{mM}$ glucose islets from tolbutamide-fed rats generated
$172 \pm 12(n=16)$ compared with $267 \pm 22(n=$ 19) $\mathrm{dpm} / \mu \mathrm{g}$ DNA in controls $(P<0.01)$. In the presence of $16.6 \mathrm{mM}$ glucose the respective values were $741 \pm 55(\mathrm{n}=18)$ vs. $939 \pm 70(\mathrm{n}=18)$ $\mathrm{dpm} / \mu \mathrm{g}$ DNA $(P<0.025)$. The $\mathrm{n}$-values indicate the number of individual observations obtained from 10 pancreata per group. The animals were sacrificed $24 \mathrm{~h}$ after the last tolbutamide dose.

Glucose-induced $(2.0,8.0$ or $16.6 \mathrm{mM}) \mathrm{IRI}$ release was lower from islets of tolbutamide-treated rats than from the appropriate controls. The respective differences were more pronounced $24 \mathrm{~h}$ than $2 \mathrm{~h}$ after the last dose. In addition, leucine-induced (12.5 or 25.0 $\mathrm{mM}$ ) IRI release was lower from islets of tolbutamide-fed rats compared with controls (Table 2).

The addition of theophylline $(5.0 \mathrm{mM})$ to the glucose stimulus $(16.6 \mathrm{mM})$ enhanced and nearly normalized the diminished IRI release from islets isolated 24 or $2 \mathrm{~h}$ after the last tolbutamide dose. By contrast, theophylline had only slight additional effects on glucose-induced (16.6 mM) IRI release from control islets (Table 3). The mean increment of IRI release $2 \mathrm{~h}$ after tolbutamide was $11.6 \mathrm{ng} / 10$ islets $/ 45 \mathrm{~min}(28 \%)$ vs $5.2 \mathrm{ng} / 10$ islets/45 $\mathrm{min}(11 \%)$ in control islets. $24 \mathrm{~h}$ after tolbutamide the mean increment was $25.8 \mathrm{ng} / 10$ islets $/ 45 \mathrm{~min}(45 \%)$ vs 7.0 $\mathrm{ng} / 10$ islets/45 $\mathrm{min}(11 \%)$ respectively.

\section{Discussion}

Our data show an increase in the amount of extractable DNA and protein from islets following prolonged administration of tolbutamide, thereby indicating an increase in islet size. This increase in islet size seems to be due to an increase in cell number rather than in individual cell size, i. e. islet cell hyperplasia, because the protein/DNA ratio remained almost unchanged (Table 1). Our findings are compatible with the histomorphological observation of increased islet growth following prolonged administration of

Table 1. Effect of long-term administration of tolbutamide on the content of insulin, DNA and protein from isolated rat islets. Mean values \pm $S E M$ are shown with the number of individual observations obtained from 10-15 pancreata in parentheses. An asterisk indicates a significant difference from the respective control value $(p<0.05$ or less). Values for " $p$ " were calculated by the " $t$ " test based on nonpaired comparisons

\begin{tabular}{lllllll}
\hline & $\begin{array}{l}\text { Feeding period } \\
\text { (days) }\end{array}$ & $\begin{array}{l}\text { Last tolbutamide dose } \\
\text { prior to sacrifice (h) }\end{array}$ & $\begin{array}{l}\text { DNA } \\
\text { (ng/islet) }\end{array}$ & $\begin{array}{l}\text { Protein } \\
\text { (ng/islet) }\end{array}$ & $\begin{array}{l}\text { Protein/DNA } \\
\text { (ratio) }\end{array}$ & $\begin{array}{l}\text { Insulin } \\
\text { (ng/islet) }\end{array}$ \\
\hline Tolbutamide & $7-9$ & 24 & - & $529 \pm 31[20]$ & - & $60 \pm 4[14]^{*}$ \\
Control & $7-9$ & 24 & - & $548 \pm 14[20]$ & - & $77 \pm 7[12]$ \\
Tolbutamide & $29-54$ & 2 & $58.0 \pm 1.2[40]^{*}$ & $774 \pm 17[23]^{*}$ & 13.5 & $56 \pm 7[11]^{*}$ \\
Control & $29-54$ & 2 & $40.8 \pm 1.0[33]$ & $570 \pm 16[25]^{*}$ & 13.9 & $74 \pm 5[11]$ \\
Tolbutamide & $29-54$ & 24 & $56.0 \pm 1.2[40]^{*} 741 \pm 43[14]^{*}$ & 13.2 & $54 \pm 6[10]^{*}$ \\
Control & $29-54$ & 24 & $41.5 \pm 1.1[20]$ & $550 \pm 23[14]$ & 13.3 & $74 \pm 8[10]$ \\
\hline
\end{tabular}


Table 2. Effect of long-term administration of tolbutamide (29-54 days) on glucose-and leucine-induced IRI release from isolated rat islets. Mean values $\pm S E M$ are shown with the number of individual observations obtained from 10-15 pancreata in parentheses. An asterisk indicates a significant difference from the respective control value $(p<0.025$ or less). Studies on rats sacrificed $24 \mathrm{~h}$ after the last tolbutamide dose were done about 8 weeks later than the experiments with rats sacrificed $2 h$ after the last dose. Values for " $P$ " were calculated by the " $t$ " test based on nonpaired comparisons

\begin{tabular}{lcllll}
\hline Last tolbutamide dose & \multicolumn{2}{c}{ Glucose Leucine } & \multicolumn{2}{c}{ IRI release (ng/10 islets/45 min) } & Difference \\
prior to sacrifice $(\mathrm{h})$ & $(\mathrm{mM})$ & $(\mathrm{mM})$ & Tolbutamide & Control & $(\%)$ \\
\hline 2 & 2.0 & - & $9.3 \pm 0.5[34]^{*}$ & $12.9 \pm 0.7[31]$ & 28 \\
2 & 8.0 & - & $14.5 \pm 1.0[17]^{*}$ & $23.2 \pm 2.2[14]$ & 38 \\
2 & 16.6 & - & $29.0 \pm 2.4[17]^{*}$ & $39.6 \pm 2.6[17]$ & 26 \\
24 & 2.0 & - & $5.4 \pm 0.7[15]^{*}$ & $10.8 \pm 1.1[15]$ & 50 \\
24 & 8.0 & - & $10.0 \pm 2.4[11]^{*}$ & $21.7 \pm 1.2[12]$ & 54 \\
24 & 16.6 & - & $20.0 \pm 1.4[12]^{*}$ & $53.0 \pm 2.4[12]$ & 63 \\
2 & - & 12.5 & $14.8 \pm 1.3[15]^{*}$ & $17.7 \pm 0.7[15]$ & 17 \\
2 & - & 25.0 & $22.7 \pm 2.0[14]^{*}$ & $30.9 \pm 3.8[12]$ & 27 \\
\hline
\end{tabular}

Table 3. Effect of theophylline on glucose-induced IRI release from isolated islets of rats long-term fed with tolbutamide. Mean values $\pm S E M$ are shown with the number of individual observations obtained from 10-12 pancreata in parentheses. An asterisk indicates a significant difference from the respective control value $(p<0.01)$. Values for " $P$ " were calculated by the " $t$ " test based on nonpaired comparisons

\begin{tabular}{|c|c|c|c|c|c|}
\hline \multirow{2}{*}{$\begin{array}{l}\text { Last tolbutamide dose } \\
\text { prior to sacrifice (h) }\end{array}$} & \multirow{2}{*}{$\begin{array}{l}\text { Glucose } \\
(\mathrm{mM})\end{array}$} & \multirow{2}{*}{$\begin{array}{l}\text { Theophylline } \\
(\mathrm{mM})\end{array}$} & \multicolumn{2}{|c|}{ IRI release $(\mathrm{ng} / 10$ islets $/ 45 \mathrm{~min})$} & \multirow{2}{*}{$\begin{array}{l}\text { Difference } \\
(\%)\end{array}$} \\
\hline & & & Tolbutamide & Control & \\
\hline 2 & 16.6 & - & $29.5 \pm 2.1[20]^{*}$ & $42.4 \pm 2.0[20]^{*}$ & 30 \\
\hline 2 & 16.6 & 5.0 & $41.1 \pm 1.7[40]$ & $47.6 \pm 2.7[40]$ & 14 \\
\hline 24 & 16.6 & - & $22.0 \pm 1.3[16]^{*}$ & $54.0 \pm 2.2[16]^{*}$ & 59 \\
\hline 24 & 16.6 & 5.0 & $47.8 \pm 1.6[40]$ & $61.0 \pm 1.8[40]$ & 22 \\
\hline
\end{tabular}

tolbutamide to rats $[8-11,13]$, rabbits [12] and dogs [14]. This increased islet growth has usually been interpreted as indicative of islet hyperfunction, i.e. increased sensitivity of the mechanism responding to glucose, thereby supporting the concept of a direct beta-cytotrophic effect of sulfonylurea derivatives as the cause for the lasting blood glucose lowering action. In support of the assumption that increased islet growth may be indicative of islet hyperfunction, increased IRI release was reported from islets with hyperplasia due to pregnancy [24]. However, our data indicate that islets with hyperplasia as the result of chronic administration of tolbutamide release less IRI after stimulation with glucose or leucine than the appropriate controls (Table 2 and 3 ). This confirms and extends previous reports [16]. Tolbutamideinduced increase in islet size is thus not evidence for islet hyperfunction, as previously thought.

The reason for the tolbutamide-induced hyperplasia remains unclear, unless it is a compensatory mechanism due to the decrease of IRI content (Table
1). A low IRI content in islets could be explained by either decreased IRI synthesis and/or by continuously increased IRI release. Diminished proinsulin/ insulin synthesis has been found both after administration of tolbutamide in vitro [25-27] and after chronic administration of various sulfonylureas in vivo [16]. Whether this is reflecting a specific inhibitory effect of tolbutamide on IRI synthesis, or rather a depression of overall islets metabolism, is not known. Impaired glucose metabolism in isolated islets could be expected to interfere with IRI synthesis. Diminished glucose oxidation in islets from longterm tolbutamide-fed rats has been reported and is confirmed here. Further data on the effect of chronic administration of sulfonylureas on islet cell metabolism are lacking. In vitro administration of sulfonylurea compounds seems to lower the ATP and the glucose-6-phosphate content of isolated islets [28, 29] even though the islet oxygen consumption and lactate production is increased [30,31]. Thus, despite some evidence to the contrary $[32,33]$, sulfonylureas 
may uncouple oxidative phosphorylation in islets, thereby inhibiting energy producing reactions required for IRI synthesis. The low IRI content in islets from long-term tolbutamide-fed rats may therefore be explained by diminished IRI synthesis. Continuously increased IRI release does not seem to be a contributing factor.

IRI release is diminished in response to glucose and leucine (Table 2). This diminished secretory response to a glucose or leucine stimulus could be the consequence of the low synthetic activity and the decreased availability of IRI. If this is the only possible explanation, major changes in the secretory pattern of the islets should not be observed. However, there was an alteration in the theophylline-sensitivity of these islets. Theophylline enhanced the effect of a glucose stimulus $(16.6 \mathrm{mM})$ on IRI release significantly more in islets from tolbutamide-fed rats than from controls (Table 3).

The combined effects of theophylline and glucose on IRI release have repeatedly been investigated and have led to conflicting results. Theophylline was reported to stimulate IRI release in the presence of a low glucose concentration $(1 \mathrm{mg} / \mathrm{ml})$ [34], an effect not seen by others [35]. Furthermore, while theophylline was found to stimulate IRI release much more in the presence of high than of low glucose concentrations [35], there are also observations to the contrary [36]. In the presence of a high glucose concentration (16.6 $\mathrm{mM}$ ) we found a small effect of theophylline on IRI release. However, these various observations reflect differences mainly in the quantity but not in the quality of the observed effects.

Theophylline is thought to modulate the secretory process of the B-cell via the adenylate cyclase/ phosphodiesterase system [37-42]. The lowered sensitivity of the B-cell insulin releasing mechanism induced by prolonged treatment with tolbutamide may, therefore, be partially effected by an interference with the enzymatic system generating and inactivating cyclic adenosine monophosphate. However, studies on the effect of sulfonylureas on islet tissue should consider that normal and diabetic islet tissue might act differently towards these agents, as recently suggested [43].

Acknowledgments. The study was supported by the Deutsche Forschungsgemeinschaft (grant Scha 246/1 and Fr 264/4). The skilful technical assistance of J. Arends, B. Hillebrecht, U. Kleinschmidt and R. Tschachlitz is highly appreciated.

\section{References}

1. Creutzfeldt, W.: Current views on the mode of action of hypoglycemic sulfonamides. Acta diabet. lat. 6 (suppl. 1), $201-215$ (1969)
2. Reaven, G., Dray, J.: Effect of chlorpropamide on serum glucose and immunoreactive insulin concentrations in patients with maturity-onset diabetes. Diabetes 16, 487-492 (1967)

3. Boshell, B.R., Fox, O.J., Roddam, R.F., Hill, P.S.: The effect of sulfonylurea agents on insulin secretion and insulin reserve. In: Tolbutamide . . . . after ten years (ed. W. J.H: Butterfield, W. van Westering), p. 286-297. Amsterdam: Excerpta Med. Found. I.C.S. 149,1967

4. Sheldon, J., Taylor, T. W., Anderson, J.: The effect of long-term acetohexamide treatment on pancreatic islet cell function in maturity-onset diabetes. Metabolism 15, 874-883 (1966)

5. Chu, P., Conway, M.J., Krouse, H.A., Goodner, Ch.J.: The pattern of response of plasma insulin and glucose to meals and fasting during chlorpropamide therapy. Ann. intern. Med. 68, $757-769$ (1968)

6. Duckworth, W.C., Solomon, S.S., Kitabchi, A.E.: Effect of chronic sulfonylurea therapy on plasma insulin and proinsulin levels. J. clin. Endocr. 35, 585-591 (1972)

7. Johansen, K., Ørskov, H.: The stimulatory effect on insulin secretion in long-term tolbutamide treatment. Acta Endocrinol. 71, 709-715 (1972)

8. Kracht, J., v. Holt, C., v. Holt, L.: Morphologische Befunde zur Wirkungsweise oraler Antidiabetika. Endokrinologie 34, $129-146$ (1957)

9. Gepts, W., Christophe, J., Bellens, R.: Étude expérimentale du BZ 55 sur le rat normal ou alloxanisé. Modifications morphologiques et en particulier pancréatiques. Ann. Endocr. (Paris) 17, 278 (1956)

10. Ashworth, M.A., Haist, R.E.: Some effects of BZ 55 (carbutamide) on growth of islets of Langerhans. Canad. med. Ass. J. 74, 459-464 (1956)

11. Gepts, W.: Étude histologique de l'effet des sulfamides hypoglycémiants sur les ilôts de Langerhans du rat. Ann. Endocr. (Paris) 18, 204-213 (1957)

12. Volk, B.W., Lazarus, S.S.: B-cell hyperfunction after long-term sulfonylurea treatment. Arch. Path. 78, 114-125 (1964)

13. Loubatières, A., Mariani, M.M., Alric, R., Houareau, M.M.: Étude chez le rat du dévelopement des ilôts de Langerhans sous l'effet de l'administration chronique, separée ou combinée, de tolbutamide et de diazoxide. C.R. Soc. Biol. (Paris) 162, 191-196 (1968)

14. Loubatières, A., Ribes, G., Mariani, M.M., Alric, R.: Pharmacological comparison between tolbutamide and two second generation hypoglycemic sulfonylureas (glibenclamide and glisoxepide). Acta diabet. lat 10, 261-282 (1973)

15. Creutzfeldt, W., Geginat, G.: Glukosetoleranz and InseIregeneration bei teilpankreatektomierten Ratten unter ACTH und langfristiger Behandlung mit N-(4-Methyl-benzolsulfonyl)N'-butylharnstoff. Arzneimittel-Forsch. 8, 464-469 (1958)

16. Dunbar, J.C., Foa, P.P.: An inhibitory effect of tolbutamide and glibenclamide (glyburide) on the pancreatic islets of normal animals. Diabetologia 10, 27-35 (1974)

17. Sodoyez, J.C., Sodoyez-Goffaux, F., Dunbar, J.C., Foa, P.P.: Reduction in the activity of the pancreatic islets induced in normal rodents by prolonged treatment with derivatives of sulfonylurea. Diabetes 19,603-609. (1970)

18. Sodoyez, J. C., Sodoyez-Goffaux, F.: Effect of daily injection of tolbutamide into pregnant rats on the pancreatic insulin content of their offspring. Metabolism 22, 1389-1393 (1973)

19. Bates, R.W., Garrison, M.M.: Daily changes in concentration of pancreatic and serum insulin and of blood glucose during 5 days of treatment of rats with growth hormone, ACTH, cortisol, dexamethasone, and tolbutamide alone and in combinations. Metabolism 23, 947-965 (1974)

20. Schauder, P., Frerichs, H.: Cytochalasin B.: Inhibition of 
glucose-induced insulin release from isolated rat pancreatic islets. Diabetologia 10, 85-87 (1974)

21. Lacy, P.E., Kostianovsky, M.: Method for the isolation of intact islets of Langerhans from rat pancreas. Diabetes 16, 35-39 (1967)

22. Gerner, L., L'Age-Stehr, J., Tjioe, T.O., Wacker, A.: Zur Isolierung Langerhansscher Inseln aus Rattenpankreas. Hoppe-Seylers Z. physiol. Chem. 351, 309-312 (1970)

23. Melani, F., Ditschuneit, H., Bartelt, K.M., Friedrich, H., Pfeiffer, E.F.: Über die radioimmunologische Bestimmung von Insulin im Blut. Klin. Wschr. 43, 1000-1007 (1965)

24. Green, I. C., Taylor, K.W.: Effect of pregnancy in the rat on the size and insulin secretory response of the islets of Langerhans.J. Endocr. 54, 317-352 (1972)

25. Morris, G.E., Korner, A.: The effect of glucose on insulin biosynthesis by isolated islets of Langerhans of the rat. Biochim. biophys. Acta (Amst.) 208, 404-413 (1970)

26. Tjioe, T.O., Wacker, A.: Einfluß oraler Antidiabetika auf die Proinsulinbiosynthese bei der Ratte. Arzneimittel-Forsch. 22, 1890-1892 (1972)

27. Schatz, H., Maier, V., Hintz, M., Nierle, C., Pfeiffer, E.F.: The effect of tolbutamide and glibenclamide on the incorporation of ${ }^{3} \mathrm{H}$ leucine and on the conversion of proinsulin to insulin in isolated pancreatic islets. FEBS Letters 26, 237-240 (1972)

28. Hellman, B., Idahl, L.A., Danielsson, A.: Adenosine triphosphate levels of mammalian pancreatic B cells after stimulation with glucose and hypoglycemic sulfonylurea. Diabetes 18, 509-516 (1969)

29. Idahl, L.A.: Glucose-6-phosphate content in mammalian pancreatic $\beta$-cells. Effects of various stimulators and inhibitors of insulin release. Hormones 2, 371-377 (1971)

30. Stork, H., Schmidt, F.H., Hellerström, C., Westman, S.: Respiration of the $\beta$-cells in the presence of sulfonylureas. In: The structure and metabolism of pancreatic islets (ed. S. Falkmer, B. Hellman, I. B. Täljedal), pp. 331-336. Oxford and New York: Pergamon Press 1970

31. Westman, S., Hellerström, C.: Metabolism of the pancreatic beta-cells of mice in the presence of hypoglycemic sulfonylureas. Postgrad. med. J., Suppl. 46, 28-31 (1970)

32. Georg, R.H., Sussman, K.E., Leitner, J.W., Kirsch, W.M.:
Inhibition of glucose and tolbutamide-induced insulin release by iodoacetate and antimycin A. Endocrinology 89, 169-176 (1971)

33. Krzanowsky, J.J., Jr., Fertel, R., Matschinsky, F.M.: Energy metabolism in pancreatic islets of rats. Studies with tolbutamide and hypoxia. Diabetes 20, 598-606 (1971)

34. Malaisse, W.J., Malaisse-Lagae, F., Mayhew, D.: A possible role for the adenylcyclase system in insulin secretion. J. clin. Invest. 46, 1724-1734 (1967)

35. Lacy, P.E., Young, D.A., Fink, C. J.: Studies on insulin secretion in vitro from isolated islets of the rat pancreas. Endocrinology 83, 1155-1161 (1968)

36. Coll-Garcia, E., Gill, J.R.: Insulin release by isolated pancreatic islets of the mouse incubated in vitro. Diabetologia 5 , $61-68(1969)$

37. Sams, D.J., Montague, W.: The role of adenosine $3^{\prime}: 5^{\prime}$-cyclic monophosphate in the regulation of insulin release. Biochem. J. 129, 945-952 (1972)

38. Kuo, W.N., Hodgins, D.S., Kuo, F.J.: Adenylate cyclase in islets of Langerhans. J. biol. Chem. 248, 2705-2711 (1973)

39. Bowen, V., Lazarus, N. R.: Glucose-mediated insulin release: 3',5'-phosphodiesterase. Diabetes 22, 738-743 (1973)

40. Montague, W., Howell, S.L.: The mode of action of adenosine $3^{\prime}: 5^{\prime}$ cyclic monophosphate in mammalian islets of Langerhans. Biochem. J. 134, 321-327 (1973)

41. Goldfine, I.D., Perlman, R., Roth, J.: Inhibition of 3', 5'-AMP phosphodiesterase in islet cells and other tissues by tolbutamide Nature 234, 295-297 (1971)

42. Bowen, V., Lazarus, N. R.: Insulin release from the perfused rat pancreas. Mode of action of tolbutamide. Biochem. J. 142, $385-389$ (1974)

43. Loreti, L., Sugase, T., Foa, P.P.: Diural variations of serum insulin, total glucagon, cortisol, glucose and free fatty acids in normal and diabetic subjects before and after treatment with chlorpropamide Hormone Res. 5, 278-292 (1974)

Dr. P. Schauder

Med. Univ.-Klinik

3400 Göttingen

Humboldtallee 1 